Open Access

\title{
Application of partial least square in predicting e-entrepreneurial intention among business students: evidence from Pakistan
}

\author{
Hira Batool, Haroon Rasheed, Muhammad Imran Malik and Saddam Hussain
}

\author{
* Correspondence: \\ ali.aneeza@yahoo.com \\ COMSATS Institute of Information \\ Technology, Attock City, Punjab, \\ Pakistan
}

\begin{abstract}
Statistics have shown that the market is oversupplied with young and inexperienced graduates as the number of graduates has been increasing over the years. At the same time, the youth's intention toward internet due to growing funds which assist web advancement in Pakistan has steadily increased. Hence, to solve the unemployment issue among business students, there is a potential to make this self-employment an option for graduates to start on their careers. The entrepreneurial attitude orientation (EAO) scale was used to measure the students' e-entrepreneurial attitudes with mediating role of self-efficacy between creativity and e-entrepreneurial intention. A survey approach was adopted by sending questionnaires to 2420 students of public and private universities. Results show that personal control, self-esteem, and creativity with mediating role of self-efficacy were found to have significant and positive relationships with online self-employment intention. Meanwhile, achievement was found to have no significant relationship with online self-employment intention. These findings provide important insight to promote and produce a positive image of e-entrepreneurship as a career. Furthermore, the results show that the effect creativity or innovativeness is mediated by entrepreneurial self-efficacy. The results of the study provide educators, administrators, and policy makers inside and outside universities valuable insights with respect to e-entrepreneurship education. It may serve students better by increasing its focus on entrepreneurial self-efficacy and need for achievement.
\end{abstract}

Keywords: Business students; Self-efficacy; Online business; Intention; EAO

\section{Background}

\section{Introduction}

Online social networking has infiltrated people's daily life with stunning rapidity to become an important social platform for computer-mediated communication (Powell 2009). Research revealed that the majority of the undergraduates had thought about starting a business, although most of them did not start right after graduation and rather postponed it to a more distant future. This reflected that there is a lack of attitudinal initiative among undergraduates to be a cyber entrepreneur. Thus, it is important to explore the attitudinal factors that influence the undergraduates' perceptions toward cyber entrepreneurship as to enhance their entrepreneurial initiative. Identified factors such as social identity, tele presence, and altruism which could affect the use of social network service by individuals. Another past research by emphasized on limited modes of social influence which

\section{空 Springer}

(c) 2015 Batool et al. Open Access This article is distributed under the terms of the Creative Commons Attribution 4.0 International License (http://creativecommons.org/licenses/by/4.0/), which permits unrestricted use, distribution, and reproduction in any medium, provided you give appropriate credit to the original author(s) and the source, provide a link to the Creative Commons license, and indicate if changes were made. 
encompass social identity, subjective norm, and group norm in investigating why students use online system. Although the respondents of this study were business students, most of them were Facebook users. Nabi and Golden (2008) commented that entrepreneurial activities among the graduates can be one of the solutions to unlock unemployment issue through targeting their attitude. Moreover, the integration of social networking sites could revolutionize the traditional way of conducting business and creates indefinite opportunities to the business (Shih 2009; Baker and Green 2008). In Pakistan, the government endeavors greatly in strengthening the policy to develop quality cyber entrepreneurs who are at same standard with that international entrepreneur. Therefore, it is worthy to have an in-depth discussion on such issue. Fayolle and Gailly (2013) studied the educational role in changing student intention toward starting their business and recommend studying other factors that can change the attitudinal aspect of students. The educational factor is not enough in changing student intention toward starting their business (Liñan and Rodríguez-Cohard 2015).

Similarly, many studies have been conducted to investigate the characteristics of entrepreneurs (Crant 1996; Douglas and Shepherd 2002; Thrikawala et al. 2011). commented that most of the previous studies on entrepreneurs heavily emphasized on personality and demographic approaches. These approaches that they stated are suffering with some problems that make them inappropriate to measure the entrepreneurs' characteristics. Attitude is a good approach to describe entrepreneurship. They have developed an entrepreneurial attitude orientation (EAO) scale which is tested to be high in validity and reliability. Due to the needs to encourage universities' undergraduates to explore e-entrepreneurship, it is thus essential to understand how to develop and nurture potential entrepreneurs. The research question is whether the universities' undergraduates' attitudes toward e-entrepreneurship have a significant relationship with their selfemployment intentions. Therefore, this study is taken to predict the entrepreneurship among universities' undergraduates adopting the EAO model. In addition, in entrepreneurship research, mediating processes are rarely studied and, therefore, it is less clear whether attitudinal characteristics such as innovativeness will have an indirect influence on entrepreneurial intentions through their effect on self-efficacy. It is worthy to note that all studies were conducted predominantly in western countries; no study has so far tried to explain relative contribution of attitudinal factors for students' e-entrepreneurial intentions in a Pakistani context. Our paper aims at filling this gap.

\section{Theoretical framework and hypotheses Theoretical framework}

E-entrepreneurial intention has been defined as the intention to start a new business through means of internet, the intention to own an online business, or the intention to be self-employed (Zhao et al. 2010). Young graduates who observe entrepreneurship as their second or even last choice of employability do not prefer this as their career (Thrikawala et al. 2011). The person verdict to choose an entrepreneur as a career is sometimes assumed to depend on personality traits. The theory of planned behavior (Ajzen 2013) has become the most popular used theoretical framework in past studies of entrepreneurial intention. According to the theory of planned behavior (TPB), human action is guided by three kinds of considerations: beliefs about the likely outcomes of the behavior and the evaluations of these outcomes (behavioral beliefs); beliefs about the normative 
expectations of others and motivation to comply with these expectations (normative beliefs); and beliefs about the presence of factors that may facilitate or impede performance of the behavior and the perceived power of these factors (Ajzen 2013). Behavioral beliefs produce a favorable or unfavorable attitude toward the behavior, normative beliefs result in perceived social pressure or subjective norm, and control beliefs give rise to perceived behavioral control. Attitude toward the behavior, subjective norm, and perception of behavioral control determine intention. The more favorable the attitude and subjective norm, and the greater the perceived control, the stronger should be the person's intention to perform the behavior. There are many discussions on entrepreneurship intention around the world which focus on attitude toward the behavior in an attempt to differentiate between entrepreneurs and non-entrepreneurs. However, only a few studies are done on business students and the EAO model related to e-entrepreneurial intention. Thus, it is the aim of this research to shed some new insights to the current entrepreneurship literature. Did a survey among business students and found out that there was a significant relationship between personal trait factor or attitude toward the behavior and the selfemployment intention. However, they examine this personal traits factor in general as the way an individual thinks and behaves without focusing on achievement in business, innovation in business, perceived personal control of business outcomes, and perceived self-esteem in business (EAO model). Prior research done on final year business management undergraduates through using the entrepreneurial attitude orientation model and their result show that there is a significant difference between undergraduates minored in entrepreneurship courses and non-entrepreneur undergraduates in terms of self-esteem and personal control, with the mean for the entrepreneur undergraduates group being higher in personal control (Shariff and Saud 2009).

Hence, there is no significance difference in terms of innovation and achievement. Xue et al. (2011) did a survey on university students from two public universities and two private universities and claimed that there was a positive significance between the need for achievement and entrepreneurial intentions of students to start a business. However, the moderate relationship between the need for achievement and entrepreneurial intention shows there is a variation on level of need for achievement. Shariff and Saud's (2009) findings are also quite contradicted with what have been found by (Nga and Shamuganathan 2010). Who did a survey on college and undergraduates from private higher educational institutions using the "Big Five" personality measure (Big Five model) found out those personality traits such as agreeableness, openness, and conscientiousness generally gave a positive influence on social entrepreneurship dimensions. The items under openness and conscientiousness are quite similar with innovation and achievement items in the EAO model, respectively. The study found that openness exerted a significant positive influence on financial returns and social vision, whereas conscientiousness was found to exert a positive influence on sustainability and financial returns. In addition, conclude that "Big Five" personality measure on undergraduates in institution of higher learning agreed that entrepreneurial intention was positively correlated with openness but not conscientiousness.

Undergraduates in three private universities agreed that there was no significant effect of need for achievement toward entrepreneurial intention besides internal control (Ismail et al. 2013). They claimed that both independent variables may be affected by other variables. According to Jusoff et al. (2009), conscientiousness was associated with diligence, organization, and persistence, which suits self-employment but at the same 
time it also suits in a larger organization, whereas open individuals tend to be curious, imaginative, adventures, and receptive to business opportunities. Besides openness, Jusoff (2009) also found that extraversion was significant which describes the extent to which people are active, energetic, and enthusiastic.

\section{Hypotheses}

Achievement Achievement can be defined as behavior toward competition with a standard of excellence (McClelland et al. 1951). Meanwhile, achievement refers to expectations of doing something better or faster than anybody else or better than the person's own earlier accomplishments. In entrepreneurship context, "achievement" refers to the perceived results and outcomes of creating a new business which significantly influence one's propensity to take the challenges and responsibilities of starting and growing a new business (McClelland 1961). Some studies indicated that the need for achievement is one the strongest predictor of entrepreneurial behaviors (McClelland 1961; Babb and Babb 1992). The study results of showed that achievement is found to be higher in entrepreneurially inclined students, as compared to entrepreneurially noninclined students. In line with this, the following hypothesis is developed:

Hypothesis 1: Achievement will influence students' e-entrepreneurial intentions positively.

Personal control Personal control can be defined as the need to do and say as one likes despite conventional expectations. Personal control belongs to the most frequently stated reasons for becoming self-employed (Kolvereid 1996). According to many individuals leave their traditional jobs to become entrepreneurs. They are tired of working for somebody else and therefore establish their own venture. Entrepreneurs do not like to be tied to rules and regulations. They want to work independently and be their "own boss". Douglas and Shepherd (2002) studied business alumni of an Australian university to determine factors influencing intentions to start a business. They suggested that having a desire of having control is an important factor affecting career decisions and the intention to start a business. Kuratko et al. (2004) found independence is a highly important determinant of the intention to start a business. This suggests the following hypotheses:

Hypothesis 2: Personal control will influence students' e-entrepreneurial intentions positively.

Creativity Creativity is usually defined either as a probability function or as an individual disposition toward risk. In other words, Creativity can be defined as a personality trait involving the willingness to pursue decisions or courses of action in a new way involving uncertainty regarding success or failure outcomes. Results of various studies are not conclusive on the relationship between creativity and entrepreneurial intentions. Stated that creativity factor significantly influences students' interest in and motivation for starting their own business. The findings of indicated that there is a statistically significant relationship between innovation risks and students' entrepreneurial intention. However, and found that risk taking or creativity is not related to entrepreneurial intention. The study thus proposes the following:

Hypothesis 3: Creativity will influence students' e-entrepreneurial intentions positively. 
Self-esteem Self-esteem is defined as the person's confidence and competencies in their thought that ultimately help in the business affairs (Ismail et al. 2013). Present self-esteem as the sense of self-associate things and awareness of un-associated things. Similarly, hand Shariff and Saud (2009)) studied self-esteem in their model and found it to be an effective determinant of intention. Correspondingly, Xue et al. (2011) also found it significant factor in determining entrepreneurial intention. It is related to a person's desire to start their own business rather than working for others if that person's ideas have not been appreciated (Kuratko et al. 2004). Therefore, on the basis of the above discussion, the following hypothesis is elicited:

Hypothesis 4: Self-esteem will influence students' e-entrepreneurial intentions positively.

Entrepreneurial self-efficacy Self-efficacy in a given domain (e.g., entrepreneurship), is based on individuals' self perceptions of their skills and abilities to accomplish a specific course of action within a given domain or achieve a desired outcome. It is the perceptions of self-efficacy rather than objective ability that motivate individuals to demonstrate entrepreneurial behavior. Empirical studies in the entrepreneurship literature have found entrepreneurs to have a higher level of self-efficacy than nonentrepreneurs. Several entrepreneurship theorists have proposed that self-efficacy plays an influential role in the new venture creation process. Some studies showed that entrepreneurial self-efficacy can be considered as one of the main personal characteristics which has a significant strong and positive impact on entrepreneurial intention, and it is a crucial factor in increasing the likelihood of business startup activity (Krueger and Carsrud 2000; Zhao et al. 2005). Therefore, on the basis of the above discussion, the following hypothesis is elicited:

Hypothesis 5: Entrepreneurial self-efficacy will influence students' e-entrepreneurial intentions positively.

Mediating effects of entrepreneurial self-efficacy Although entrepreneurial selfefficacy is often depicted as a direct predictor for entrepreneurial intentions, it can also mediate the effects of other variables (Zhao et al. 2005). The model tested in this study considers that self-efficacy can have a mediating role in the relationship between creativity and entrepreneurial intentions. Creativity relates to perceiving and acting on business activities in new and unique ways. As suggested by many scholars (Schumpeter 1936), creativity is innovativeness in the aspect of entrepreneurship and an essential entrepreneurial characteristic. Pointed out that self-efficacy for a specific domain may be influenced by four components, including one's own psychological characteristics. Suggest that the relationship between certain personalities' constructs and one's intentions can is mediated.

Hypothesis 6: Entrepreneurial self-efficacy will mediate the relationship between creativity and e-entrepreneurial intention

The literature also lends support to the formulation of the research framework for examining the relationship between entrepreneurial attitude orientation model through mediating role of self-efficacy, extent of e-entrepreneurial intention, and attitude of business students (see Fig. 1). 


\section{Methods}

\section{Data and methods}

\section{Research method}

The unit of analysis in this study is all business students in top ranked business institutes, Pakistan. The business students are mainly from last semester of business studies. Based on the general rule, the minimum number of respondents or sample size is five-to-one ratio of the number of independent variables to be tested. However, Hair et al. (2010) proposed that the acceptable ratio is ten-to-one. Non-probability purposive sampling was used in this study. Since we could not get a list of all the elements of the population, we used a non-probability sampling of purposive sampling whereby only business students were chosen and those who were not involved were excluded from the sample.

\section{Data collection}

Two hundred self-administered questionnaires were used for gathering data from the respondents. A multiple method of data collection was employed, whereby some Fig. 1 research model questionnaires were mailed to the respondents, some were e-mailed, and some were personally administered. The process of distribution and collection of questionnaires was carried out over a period of 3 months. A total of 2000 questionnaires were received and used for this analysis. The next section presents the assessment of the

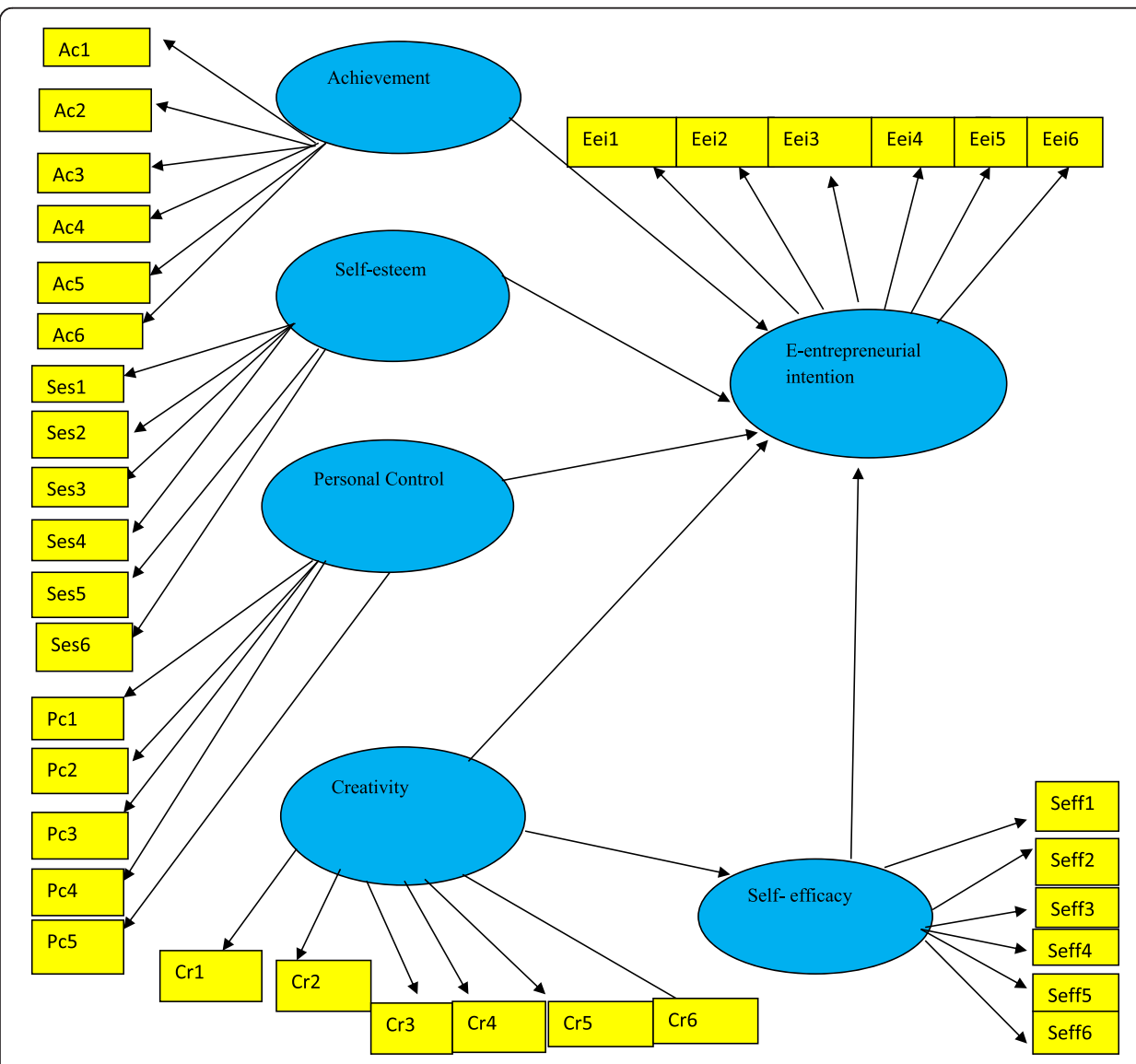

Fig. 1 Research model 
goodness of measure of these constructs in terms of their validity and reliability within the research framework.

\section{Measures and assessment of goodness of measures}

A questionnaire using a 5-point Likert scale was used to gather data for each construct of the research model. All instruments were adopted from previous literatures and were used to measure the e-entrepreneurial intention. The questionnaires were based on a multiple item measurement scale adopted from previous research namely Ismail et al. (2013).

\section{Goodness of measures}

The two main criteria used for testing goodness of measures are validity and reliability. Reliability is a test of how consistently a measuring instrument measures whatever concept it is measuring, whereas validity is a test of how well an instrument that is developed measures the particular concept it is intended to measure (Sekaran and Bougie 2010).

\section{Construct validity}

Construct validity testifies to how well the results obtained from the use of the measure fit the theories around which the test is designed (Sekaran and Bougie 2010). The question here is does the instrument tap the concept as theorized? This can be accessed through convergent and discriminant validity. First, we looked at the respective loadings and cross loadings from Table 1 to assess if there are problems with any particular items. We used a cutoff value for loadings at 0.5 as significant (Hair et al. 2010). As such, if any items which have a loading of higher than 0.5 on two or more factors, then they will be deemed to be having significant cross loadings. From Table 1, we can observe that all the items measuring a particular construct loaded highly on that construct and loaded lower on the other constructs, thus confirming construct validity.

\section{Convergent validity}

Next, we tested the convergent validity which is the degree to which multiple items to measure the same concept are in agreement. As suggested by Hair et al. (2010), we used the factor loadings, composite reliability, and average variance extracted to assess convergence validity. The loadings for all items exceeded the recommended value of 0.5 (Hair et al. 2010). Composite reliability values can be seen in Table 2).

Table 2 depicts the degree to which the construct indicators indicate the latent, construct ranged from 0.8802 to 0.8958 which exceeded the recommended value of 0.7 . The average variance extracted (AVE) measures the variance captured by the indicators relative to measurement error, and it should be greater than 0.50 to justify using a construct (Barclay et al. 1995). The average variance extracted, were in the range of 0.5571 and 0.5896 .

\section{Discriminant validity}

Next, we proceeded to test the discriminant validity. The discriminant validity of the measures (the degree to which items differentiate among constructs or measure distinct concepts) was assessed by examining the correlations between the measures of potentially overlapping constructs. Items should load more strongly on their own 
Table 1 Respective loadings and cross loadings

\begin{tabular}{|c|c|c|c|c|c|c|}
\hline & $\mathrm{ACH}$ & SES & $P C$ & $C R$ & SEFF & Eei \\
\hline$\overline{A C 1}$ & 0.9598 & & & & & \\
\hline$A C 2$ & 1.4803 & & & & & \\
\hline$A c 3$ & 0.9129 & & & & & \\
\hline Ac4 & 1.0536 & & & & & \\
\hline Ac5 & 1.2669 & & & & & \\
\hline Ac6 & 1.0847 & & & & & \\
\hline \multicolumn{7}{|l|}{ Se1 } \\
\hline Se2 & & 6.1937 & & & & \\
\hline $\mathrm{Se} 3$ & & 7.3059 & & & & \\
\hline Se4 & & 7.8859 & & & & \\
\hline Se5 & & 8.2718 & & & & \\
\hline Se6 & & 6.1950 & & & & \\
\hline PC1 & & & 6.0613 & & & \\
\hline PC2 & & & 6.4999 & & & \\
\hline PC3 & & & 7.3169 & & & \\
\hline Pc4 & & & 6.1569 & & & \\
\hline PC5 & & & 5.1784 & & & \\
\hline $\mathrm{Cr} 1$ & & & & 5.5611 & & \\
\hline $\mathrm{Cr} 2$ & & & & 7.9200 & & \\
\hline $\mathrm{Cr} 3$ & & & & 7.1418 & & \\
\hline $\mathrm{Cr} 4$ & & & & 7.1196 & & \\
\hline $\mathrm{Cr} 5$ & & & & 6.4585 & & \\
\hline $\mathrm{Cr} 6$ & & & & 5.7744 & & \\
\hline Seff1 & & & & & 10.3049 & \\
\hline Seff2 & & & & & 11.5741 & \\
\hline Seff3 & & & & & 10.2974 & \\
\hline Seff4 & & & & & 10.4169 & \\
\hline Eei1 & & & & & & 8.0163 \\
\hline Eei2 & & & & & & 9.1794 \\
\hline Eei3 & & & & & & 9.0367 \\
\hline Eei4 & & & & & & 8.5574 \\
\hline Eei5 & & & & & & 8.8081 \\
\hline Eei6 & & & & & & 10.6429 \\
\hline
\end{tabular}

Italicized values are loadings for items which are above the recommended value of 0.5

constructs in the model, and the average variance shared between each construct and its measures should be greater than the variance shared between the construct and other constructs (Compeau et al. 1999). As shown in Table 3, the diagonal values in (bold) are higher than off-diagonal ones which shows existence of discriminate validity.

\section{Reliability analysis}

We used Cronbach's alpha coefficient to assess the inter item consistency of our measurement items. Table 4 summarizes the loadings and alpha values. As seen from Table 4, 
Table 2 Composite reliability values

\begin{tabular}{|c|c|c|c|c|c|}
\hline Variable & Indicator & Loading & $\begin{array}{l}\text { Indicator reliability } \\
\text { loadings*|oadings }\end{array}$ & $\begin{array}{l}\text { Composite } \\
\text { reliability }\end{array}$ & AVE \\
\hline \multirow[t]{6}{*}{ Achievement } & $A c 1$ & 0.7006 & 0.490 & 0.8958 & 0.5896 \\
\hline & Ac2 & 0.8065 & 0.650 & & \\
\hline & Ac3 & 0.7860 & 0.617 & & \\
\hline & Ac4 & 0.7953 & 0.632 & & \\
\hline & Ac5 & 0.7932 & 0.629 & & \\
\hline & Ac6 & 0.7188 & 0.516 & & \\
\hline \multirow[t]{6}{*}{ Self-esteem } & Ses 1 & 0.6557 & 0.429 & 0.8802 & 0.5517 \\
\hline & Ses 2 & 0.7140 & 0.509 & & \\
\hline & Ses3 & 0.7938 & 0.630 & & \\
\hline & Ses 4 & 0.7821 & 0.611 & & \\
\hline & Ses 5 & 0.7851 & 0.616 & & \\
\hline & Ses6 & 0.7154 & 0.511 & & \\
\hline \multirow[t]{5}{*}{ Personal control } & PC1 & 0.7401 & 0.547 & 0.8745 & 0.5831 \\
\hline & PC2 & 0.7903 & 0.624 & & \\
\hline & PC3 & 0.8039 & 0.646 & & \\
\hline & Pc4 & 0.7961 & 0.633 & & \\
\hline & Pc5 & 0.6806 & 0.463 & & \\
\hline \multirow[t]{6}{*}{ Creativity } & $\mathrm{Cr} 1$ & 0.6814 & 0.464 & 0.8780 & 0.5466 \\
\hline & $\mathrm{Cr} 2$ & 0.7905 & 0.624 & & \\
\hline & $\mathrm{Cr} 3$ & 0.7967 & 0.634 & & \\
\hline & $\mathrm{Cr} 4$ & 0.7731 & 0.597 & & \\
\hline & $\mathrm{Cr} 5$ & 0.7177 & 0.515 & & \\
\hline & Cr6 & 0.6657 & 0.443 & & \\
\hline \multirow[t]{4}{*}{ Self-efficacy } & Sef1 & 0.8197 & 0.671 & 0.8967 & 0.6846 \\
\hline & Sef2 & 0.8355 & 0.698 & & \\
\hline & Sef3 & 0.8356 & 0.698 & & \\
\hline & Sef4 & 0.8185 & 0.669 & & \\
\hline \multirow{6}{*}{$\begin{array}{l}\text { E-entrepreneurial } \\
\text { intention }\end{array}$} & Eei1 & 0.7096 & 0.503 & 0.8910 & 0.5771 \\
\hline & Eei2 & 0.7683 & 0.590 & & \\
\hline & Eei3 & 0.7894 & 0.623 & & \\
\hline & Eei4 & 0.7406 & 0.548 & & \\
\hline & Eei5 & 0.7483 & 0.559 & & \\
\hline & Eei6 & 0.7985 & 0.637 & & \\
\hline
\end{tabular}

Composite reliability $(C R)=$ (square of the summation of the factor loadings)/\{(square of the summation of the factor loadings) + (square of the summation of the error variances)

Average variance extracted $(\mathrm{AVE})=$ (summation of the square of the factor loadings)/(summation of the square of the factor loadings) + (summation of the error variances) $\}$

all alpha values are above 0.6 as suggested by Nunnally and Berstein (1994). The composite reliability values also ranged from 0.8203 to 0.8921 . Interpreted like Cronbach's alpha for internal consistency reliability estimate, a composite reliability of 0.70 or greater is considered acceptable (Fornell and Larcker 1981). As such, we can conclude that the measurements are reliable. 
Table 3 The discriminant validity of the measures

\begin{tabular}{lllllll}
\hline Discriminant valid & & & & & \\
\hline Achievement & $\mathbf{1 . 0 0 0 0}$ & & & & & \\
E-entrepreneurial intention & 0.1405 & $\mathbf{1 . 0 0 0 0}$ & & & & \\
Creativity & 0.1214 & 0.5971 & $\mathbf{1 . 0 0 0 0}$ & & \\
Personal control & 0.1461 & 0.6143 & 0.6250 & $\mathbf{1 . 0 0 0 0}$ & & \\
Self-efficacy & 0.1689 & 0.7149 & 0.5655 & 0.5931 & $\mathbf{1 . 0 0 0 0}$ & \\
Self-esteem & 0.0790 & 0.6612 & 0.6109 & 0.5991 & 0.6489 & $\mathbf{1 . 0 0 0 0}$
\end{tabular}

Note: Values in the diagonal (bolded) are square root of the AVE while the off-diagonals are correlations

\section{Results and discussion}

\section{Hypotheses testing}

Next, we proceeded with the path analysis to test the four hypotheses generated. Figure 2 and Table 5 present the results. The R2 value was 0.612 suggesting that $61.2 \%$ of the variance in extent of e-entrepreneurial intention can be explained by achievement, self-esteem personal control, and innovation through self-efficacy. Similarly, innovation explains $32 \%$ variance in the self-efficacy. A close look shows that self-esteem was positively related $(b=$ 0.2267, $p \backslash 0.01$ ) to extent of e-entrepreneurial intention and so was personal control, innovation, and self-efficacy $(b=0.1575, p \backslash 0.01),(b=0.1344, p \backslash 0.01),(b=0.3956, p=\backslash 0.01)$, whereas achievement was not a significant predictor of e-entrepreneurial intention.

\section{Mediation analysis}

Hair et al. (2014) define mediation as the translator that carries forward the influence of independent variable on the dependent variable. Both recommend the mediation analysis through a diagram by using Smart PLS (Fig. 3).

Hair et al. (2014) proposed a method for checking whether the mediation is full, partial, or no mediation (see Fig. 4).

\section{Mediation analysis of the research model}

Total effect through bootstrapping is used to test the mediation analysis that fulfill the Hair et al. (2014) criteria for assessing the mediation effect, and later on, the VAF calculation proves the full mediation exist through self-efficacy between innovation and eentrepreneurial intention. The presentation for the mediation effect is shown in Fig. 5.

\section{Discussion}

As the attitudinal aspect of self-esteem, personal control, and innovation through selfefficacy has been found statistically significant with the e-entrepreneurial intention.

Table 4 Summary of the loadings and alpha values

\begin{tabular}{llll}
\hline Constructs & Measurement items & Cronbach's alpha & Measurement items \\
\hline Achievement & ac1, ac2, ac3, ac4, ac5, ac6 & 0.8601 & 6 \\
Self-esteem & ses1, ses2, ses3, ses4, ses5, ses6 & 0.8364 & 6 \\
Personal control & pc1, pc2, pc3, pc4, pc5 & 0.8203 & 5 \\
Creativity & inn1, inn2, inn3, inn4, inn5, inn6 & 0.8326 & 6 \\
E-entrepreneurial & eei1, eei2, eei3, eei4, eei5, eei6 & 0.8532 & 6 \\
Intention & & & 6 \\
Self-efficacy & seff1, seff2, seef3, seff4, seff5, seff6 & 0.8921 & \\
\hline
\end{tabular}




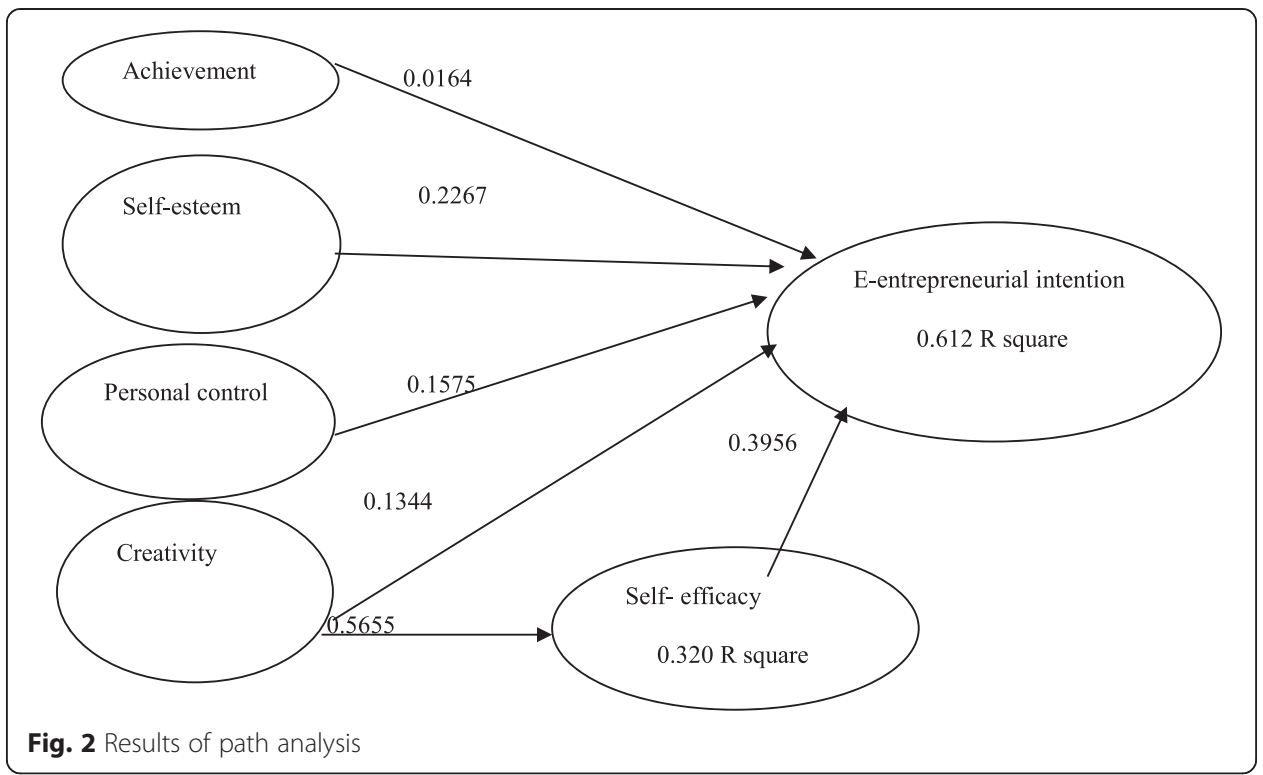

Conversely, the achievement has been found as an insignificant predictor of the student self-employment intention. Hence, $\mathrm{H} 2, \mathrm{H} 3, \mathrm{H} 4, \mathrm{H} 5$, and $\mathrm{H} 6$ are accepted as the result of this study. The finding on H1as achievement factor shows that business students who perceived to have concrete results in business do not intent to start their online business. Ismail et al. (2013) highlight that achievement is sometimes dependent on other human attitudinal aspects like personal control and self-esteem. So, students who supposed achievement in business do not make any difference toward starting their online business. Added that achievement is needed in the large business organization, not in starting a business so it becomes push factor for the individual to start their online business. The result on achievement is similar to studies done in different countries that shows insignificant impact of achievement on entrepreneurial intention. So, this findings support the claim in e-entrepreneurial intention as well. The significant relationship between through $\mathrm{H} 2$ self-esteem and e-entrepreneurial intention extend the previous findings that support if a person has self-confidence in their thought than it extends their intention of starting a business and it also works under starting a business in unique way (online business) (Ismail et al. 2013; Shariff and Saud 2009). Similarly, H3 personal control supports the claim made by studies conducted in Malaysia that eentrepreneurial intention is affected by having control and influence over the business (Shariff and Saud 2009), and this also works for starting their online business (Fayolle and Gailly 2013). H4 extend previous finding on creativity term in relation with entrepreneurial

Table 5 Path analysis to test the four hypotheses generated

\begin{tabular}{|c|c|c|c|c|}
\hline Hypothesis & Relationship & Coefficient & $t$ value & Supported \\
\hline $\mathrm{H1}$ & Achievement $\rightarrow$ e-entrepreneurial intention & 0.0164 & 0.2099 & No \\
\hline $\mathrm{H} 2$ & Self-esteem $\rightarrow$ e-entrepreneurial intention & 0.2267 & 2.3353 & Yes \\
\hline $\mathrm{H} 3$ & Personal control $\rightarrow$ e-entrepreneurial intention & 0.1575 & 1.9822 & Yes \\
\hline $\mathrm{H} 4$ & Creativity $\rightarrow$ e-entrepreneurial intention & 0.1344 & 1.9978 & Yes \\
\hline H5 & Self-efficacy $\rightarrow$ e-entrepreneurial intention & 0.3956 & 3.3586 & Yes \\
\hline H6 & Creativity self-efficacy $\rightarrow$ e-entrepreneurial intention & 0.5655 & 5.8169 & Yes \\
\hline
\end{tabular}




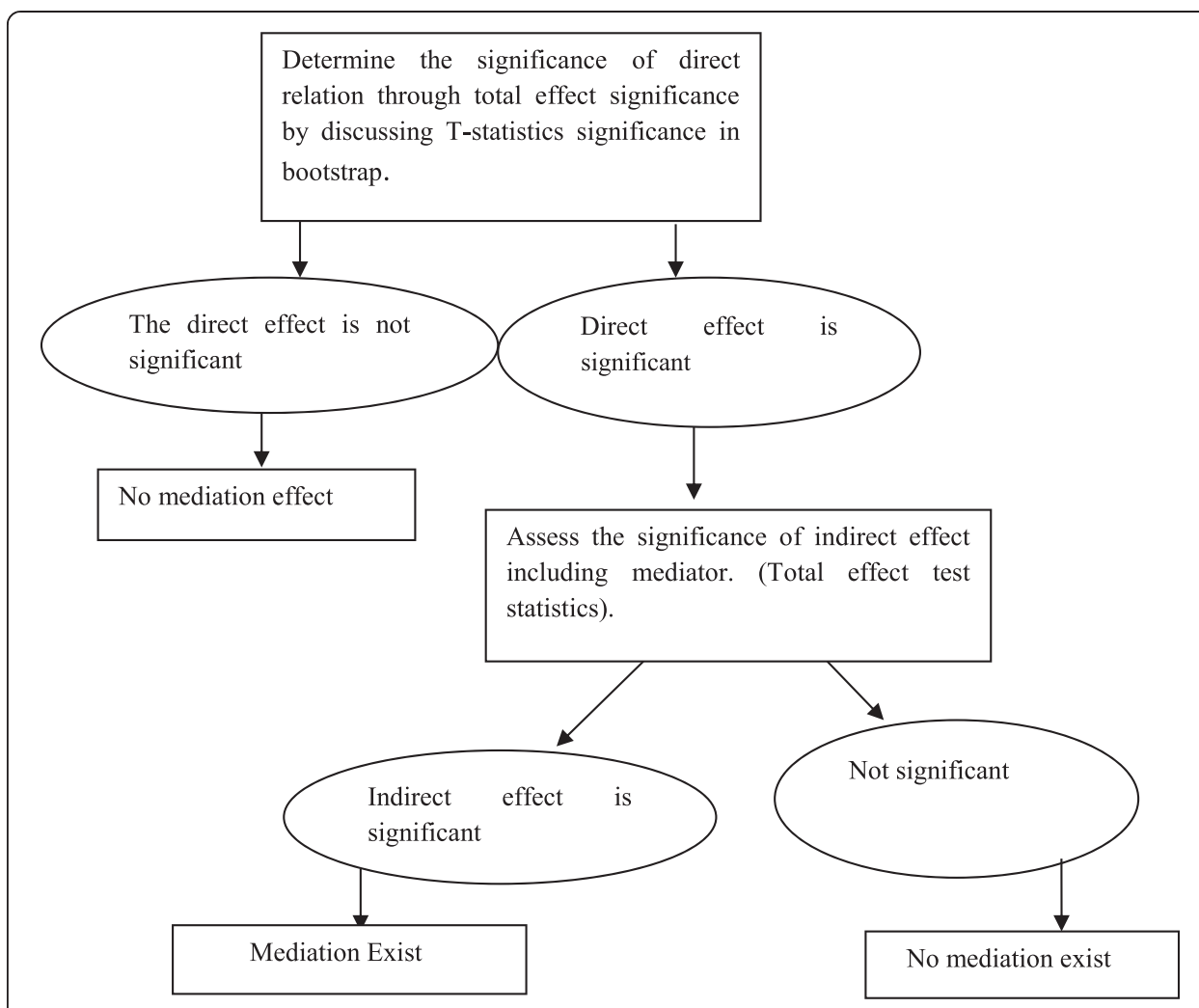

Fig. 3 Diagram using Smart PLS of recommended mediation analysis (Taken from Hair et al. (2014))

intention confirms that the finding of Nga and Shamuganthan (2010) that through a desire of doing business in a unique way is the only one directly related with starting an online business.

Entrepreneurial attitude orientation model in coincidence with e-entrepreneurial intention support that model works in building undergraduates intention toward starting online business. Statistical facts revealed that having more perception about control and influence over business will have greater intention toward starting their online business. In support of self-esteem and creativity, undergraduates who have more intention toward starting a business in a unique way are those who have competency and self-confidence in their ability. So, the findings of the study are similar with the existing literature on selfemployment intention by using the EAO model (Ismail et al. 2013; Shariff and Saud 2009; Nga and Shamuganthan 2010). H5 self-efficacy as the contribution to the EAO model shows positive significant relation with e-entrepreneurial intention with $\beta=0.3956, t>$ 1.96. By $100 \%$ changing the aspect of self-efficacy will bring $39.56 \%$ change in the eentrepreneurial intention. Accordingly, H5 is accepted for the study. As variance accounted for proves full mediation exist between creativity and e-entrepreneurial intention through self-efficacy. The relationship between creativity and self-efficacy with $\beta$ of 0.5655 and $t>$ 1.96 proves that $100 \%$ change in innovation will bring $55.56 \%$ mediation effect of selfefficacy. In the view that $\mathrm{H} 6$ is accepted, variance accounted for and mediation analysis in partial least square extend the EAO model with the mediation role of self-efficacy between innovation and e-entrepreneurial intention. Previous research suggested that entrepreneurship is influenced by innovation, but in this model, the relation is largely mediated by self- 

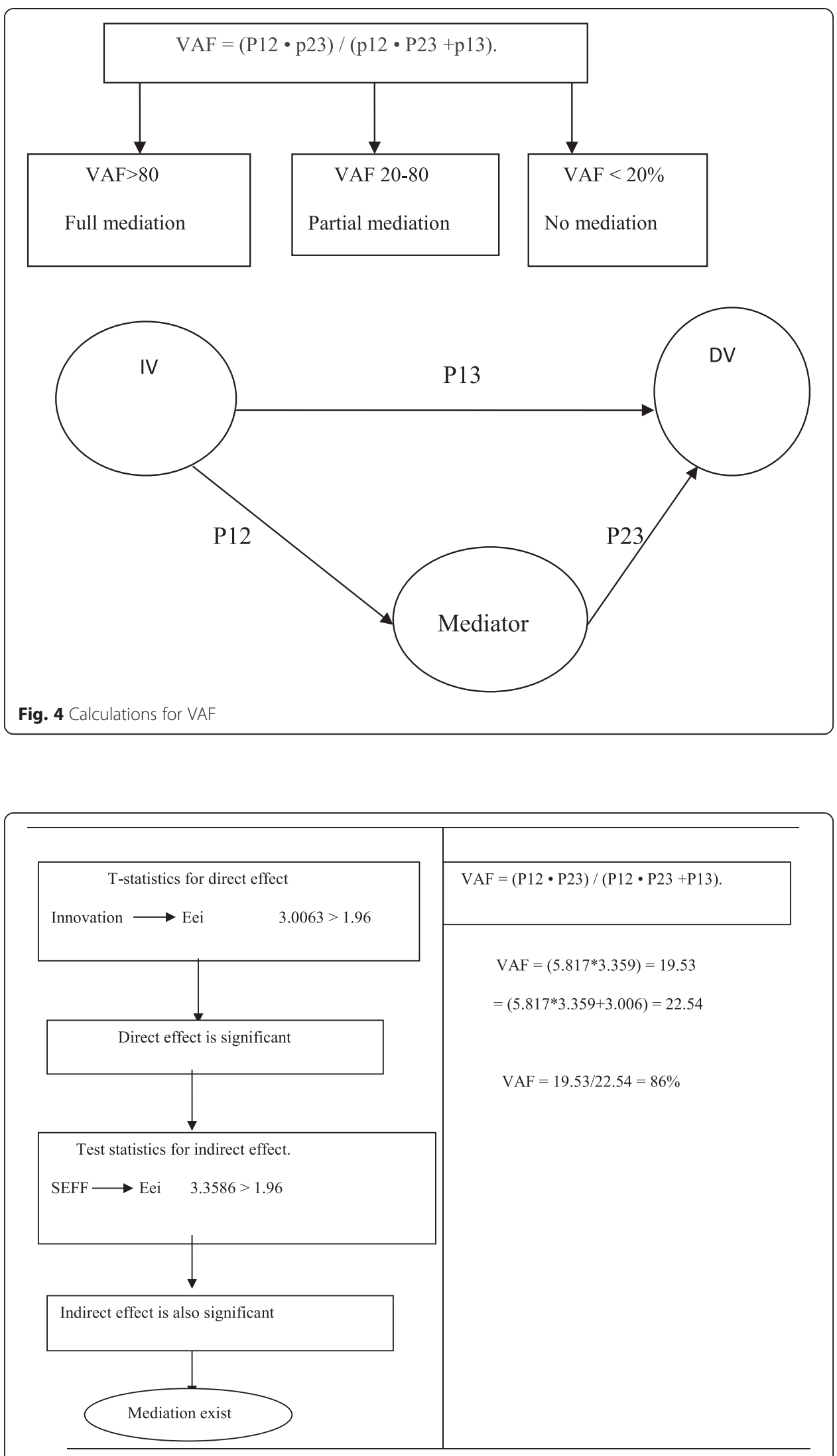

Fig. 5 Mediation and variance accounted for 
efficacy (Karimi et al., 2012). Individuals with high competency and ability are more confident in starting an online business. So, this study confirms the mediation role of selfefficacy exists between innovation and e-entrepreneurial intention (Karimi et al., 2012). This research provides helpful information and insight for educationist who put forward new educational policy. Results of the study show that intention of starting an online business is affected by attitudinal aspect of students rather than targeting their personality factor, so this study contradict with those who refer personality aspect as the main determinants of selfemployment intention (Kuratko et al. 2004; Karimi et al. 2012; Douglas and Shepherd 2002). With the reference of this study, students' intention can be changed through targeting their personal control, self-esteem, and innovation. In sort to evade unnecessary budget, educationists need to identify students with these attitudinal aspect and encourage them to participate in different online business plan competition in order to put forward their intention toward starting an online business. For example, departments or universities can try to select students in e-entrepreneur course after receiving information about student's attitude regarding self-employment.

In addition, different education programs should be considered in order to nurture abovementioned attitudinal aspect among all students. Erikson (2003) claimed that achievement and innovational aspect can be changed among students through training. Most of the entrepreneurial intention can be developed among the business students but it cannot be developed through traditional method of teaching (Krueger and Carsrud 2000). Karimi et al. (2012) highlighted that poor evaluation system and inappropriate way of teaching with a deprived design syllabus are the main barriers in any developing country that hinder the role of education sector in developing business intention among the youth. So, the society cannot expect superior role of entrepreneurial education in building e-entrepreneurial attitude. Pakistani economy with limited job opportunities and favorable conditions of technology advancement needs to focus more on entrepreneurial courses, strategies, and pedagogy contents that promote new culture of doing their own business. Such considerations help the business students from jobseekers to job-creators and indirectly improve the economic condition of Pakistan.

\section{Conclusion}

For the sake of achieving research objectives and the answers of research questions based on e-entrepreneurial intention, competing model of EAO with research framework is tested through PLS (SEM). This proves that entrepreneurial attitude orientation model also works for determining and building students intention toward online business (Ismail et al. 2013). Through using EAO model, important determinants of e-entrepreneurial intention are achieved. Some of them contribute a lot in determining the intention, while others not. Self-esteem, personal control, and innovation through self-efficacy have higher pathcoefficient than achievement. The results confirmed that attitude do have positive relation with e-entrepreneurial intention. Universities are basically considered as the providers of entrepreneurs to the society. Along with the role of universities through education and training, policy makers do need to focus on promoting and teaming a supportive environment for business. This is due to the fact that curriculum can build or change the students' attitude, but lack of supportive environment pushes them from venturing their own business. The study findings contribute to the literature by studying the EAO model in relation with e-entrepreneurial intention through adding the mediator role of self-efficacy between 
innovation and e-entrepreneurial intention. Subsequently, the model could be tested in both collectivistic and less collectivistic environments. Future studies could perhaps identify and examine specific relationships between particular male and female business students so that the issue of variance in the extent of e-entrepreneurial intention among them could be better understood.

Competing interests

The authors declare that they have no competing interests.

\section{Authors' contributions}

$\mathrm{HB}$ has made substantial contributions to the conception of design and analysis and interpretation of data. SH has given final approval of the version to be published. HS has been involved in drafting, revising it critically for important intellectual content. All authors read and approved the final manuscript.

\section{Acknowledgement}

Author of the paper is highly grateful to T. Ramayah for his writing assistance.

Received: 18 March 2015 Accepted: 23 July 2015

Published online: 15 September 2015

References

Ajzen. (June 1, 2013). Constructing a TpB questionnaire: conceptual and methodological considerations. [Online]. Available: http://people.umass.edu/aizen/tpb.html

Anon, (2013). "Tekun loans will spur economy: Najib," New Straits Times, February 9.

Babb, E, \& Babb, S. (1992). Psychological traits of rural entrepreneurs". The Journal of Socio-Economics, 21, 353-362.

Baker, S., Green, H (2008). Social media will change your business. Bloomberg Businessweek. Retrieved January 20, 2012 from http://www.businessweek.com/bwdaily/dnflash/content/feb2008/db20080219_908252.htm

Barclay, DW, Thompson, R, \& Higgins, C. (1995). The partial least squares (PLS) approach to causal modeling: personal computer adoption and use an illustration. Technol Stud, 2(2), 285-309.

Bennani, AE, \& Oumlil, R. (2014). Acceptance of e-entrepreneurship by future entrepreneurs in developing countries: case of Morocco. "Journal of Entrepreneurship": Research \& Practice, 2014(2014), 2-10.

Carrier, C, Raymond, L, \& Eltaief, A. (2004). Cyberentrepreneur: a multiple case study. International Journal of Entrepreneurial Behaviour \& Research, 10(5), 349-363.

Cheung, CMK, Chiu, PY, \& Lee, MKO. (2010). Online social networks: why do students use facebook? Computers in Human Behavior, 27(4), 1337-1343.

Compeau, DR, Higgins, CA, \& Huff, S. (1999). Social cognitive theory and individual reactions to computing technology: a longitudinal-study. MIS Quarterly, 23(2), 145-158.

Crant, JM. (1996). The proactive personality scale as a predictor of entrepreneurship intention. Journal of Small Business Management, 34(3), 42-49.

Douglas, EJ, \& Shepherd, DA. (2002). Self-employment as a career choice: attitudes, entrepreneurial intentions, and utility maximization". Entrepreneurship: Theory and Practice, 26(3), 81-90.

Erikson T. (2003). Towards a taxonomy of entrepreneurial learning experiences among potential

Fayolle A., A and Gailly B (2013). The impact of entrepreneurship education on entrepreneurial attitudes and intention: hysteresis and persistence, JSBM, online first (16 SEP 2013). http://onlinelibrary.wiley.com/doi/10.1111/jsbm.12065/abstract

Fornell, C, \& Larcker, DF. (1981). Evaluating structural equation models with unobservable variables and measurement error. Journal of Marketing Research, 18(1), 39-50.

Hair, JF, Black, WC, Babin, BJ, \& Anderson, RE. (2010). Multivariate data analysis. Upper Saddle River: Prentice-Hall.

Hair, JF, Jr, Hult, GTM, Ringle, C, \& Sarstedt, M. (2014). A primer on partial least squares structural equation modeling (PLS-SEM). Incorporated: SAGE Publications.

Ismail N., Jaffar N., Hooi TS. (2013). Using EAO model to predict the self-employment intentions among the universities' undergraduates in Malaysia. International Journal of Trade, Economics \& Finance, 4(5).

Karimi S., Biemans H.J., Lans T., Arasti Z., Chizari M., Mulder M. (2012) Application of structural equation modelling to assess the effect of entrepreneurial characteristics on students' entrepreneurial

Kolvereid, L. (1996). Prediction of employment status choice intentions. Entrepreneurship: Theory and Practice, 20(3), 45-57.

Krueger, Reilly, Carsrud. (2000) "Competing models of entrepreneurial intentions", Journal of Business Venturing, Vol.15, No.5/6, pp. 411-532

Kuratko, DF, Hornsby, JS, \& Naffziger, DW. (2004). An examination of owner's goals in sustaining entrepreneurship. Journal of Small Business Management, 35(1), 24-33.

Liñan, F, \& Rodríguez-Cohard, JC. (2015). Assessing the stability of graduates' entrepreneurial intention and exploring its predictive capacity. Academia Revista Latinoamericana de Administración, 28(1), 77-98.

McClelland, DC. (1961). The achieving society. New York: Irvington.

McClelland, DC, Atkinson, JW, Clark, RA, \& Lowell, L. (1951). The achievement motive. New York: Appleton.

Nabi, G, \& Golden, R. (2008). Graduate entrepreneurship: intentions, education and training. Education + Training, 50(7), 545-551.

Nga, JKH, \& Shamuganthan, G. (2010). The influence of personality traits and demographic factors on social entrepreneurship start up intentions. Journal of Business Ethics, 95(2), 259-282.

Nunnally, J, \& Berstein, I. (1994). Psychometric theory. New York: McGraw-Hill.

Powell, J. (2009). 33 million people in the room: how to create, influence, and run a successful business with social networking. NJ: FT Press.

Schumpeter, JA. (1936). The theory of economic development (2nd ed.). Cambridge: Harvard University Press. 
Sekaran, U, \& Bougie, R. (2010). Research methods for business: a skill building approach. UK: Wiley.

Shariff, MNM, \& Saud, MB. (2009). An attitude approach to the prediction of entrepreneurship on students at institution of higher learning in Malaysia. International Journal of Business and Management, 4(4), P129.

Shih, CCW. (2009). The Facebook era: tapping online social networks to build better products, reach new audiences, and sell more stuff. England: Prentice Hall.

Thrikawala S. "The determinants of entrepreneurial intention among academics in Srilanka," in Proc. International conference on economics and finance research, IACSIT press, Singapore, no. 4, pp. 454-458, 2011.

Xue, FT, Yoon, KT, \& Liang, CL. (2011). Factors influencing entrepreneurial intention among university student. International Journal of Social Sciences and Humanity Studies, 3(1), 487-496.

Zhao, H, Hills, GE, \& Seibert, S. (2005). The mediating role of self-efficacy in the development of entrepreneurial intentions. Journal of Applied Psychology, 90(6), 1265-1272.

Zhao, H, Seibert, SE, \& Lumpkin, GT. (2010). The relationship of personality to entrepreneurial intentions and performance: a meta-analytic review. Journal of Management, 36, 381-404.

\section{Submit your manuscript to a SpringerOpen ${ }^{\circ}$ journal and benefit from:}

- Convenient online submission

- Rigorous peer review

- Immediate publication on acceptance

- Open access: articles freely available online

- High visibility within the field

- Retaining the copyright to your article 